\title{
Taxation in the COVID-19 Pandemic: to Pay or Not to Pay
}

\author{
Frank Aragbonfoh Abumere ${ }^{1}$
}

Received: 21 October 2020 / Revised: 2 February 2021 / Accepted: 24 February 2021/ Published online: 29 March 2021

(C) The Author(s), under exclusive licence to Springer Nature B.V. 2021

\begin{abstract}
Like many governments in this COVID-19 pandemic, the Nigerian government imposed a lockdown on the country. As a consequence of the lockdown, many businesses shutdown and effectively had no source of revenue. Yet, without receiving any bailout or palliatives from the government, these businesses are required to meet their tax obligations to the government. Bearing in mind that this time (COVID-19 era) is different, one wonders what is required of businesses in view of the taxation problem and the social contract between the businesspersons and the government. In view of social contract obligations, in this COVID-19 pandemic should businesses pay tax to a government that seems to have delegitimised itself by its exploitative actions in terms of taxation and delinquent omission in terms of the provision of public goods and social services? The Nigerian government at all tiers (federal, state and local) seldom respect the essence of taxation. Therefore, businesses often pay tax for nothing. For many businesses, as far as taxation is concerned, to pay or not to pay? that is the question. This article is aimed at teasing out this taxation problem that may or may not be a moral dilemma. In view of certain ethical considerations, this article shows why in spite of social contract obligations, there is no consensus or canonical agreement on whether, as law-abiding citizens and juridical persons (legal entities), businesspersons and businesses ought to or ought not to pay tax to the Nigerian government in this COVID-19 pandemic.
\end{abstract}

Keywords COVID-19 $\cdot$ Moral dilemma $\cdot$ Nigeria $\cdot$ SMEs $\cdot$ Social contract $\cdot$ Taxation

Frank Aragbonfoh Abumere

aragbonfohabumere@gmail.com; frank.a.abumere@uit.no

1 Globalizing Minority Rights (GMR), Department of Philosophy, The Arctic University of Norway, Hansine Hansens veg 18, 9019 Tromso, Norway 


\section{Introduction}

In The Trouble with Nigeria, Chinua Achebe (1983) famously declared that the trouble with Nigeria is the failure of leadership. As shown in the next two sections, there is a direct relationship between bad governance and a taxation problem in Nigeria because the lack of confidence in the government is largely responsible for aversion to taxation. If anyone was under any illusion that the gravity of the Corona Virus (COVID-19) pandemic would prompt the Nigerian political class to resolve the failure of leadership, the ineptitude with which the government is dealing with the pandemic, and the plethora of corruption cases that are subject of inquisition at the presidency and parliament (without even mentioning the courts), reveal that it is still politics as usual.

The 2020 ENDSARS protests and revolution across Nigeria (the biggest protests in the history of the country) are a testament to the fact that bad governance is the order of the day in Nigeria. Although the ENDSARS protests have no direct relationship with the taxation problem, the protests are a reaction to bad governance which is the underlying cause of both the injustice the protesters protested against and the taxation problem. In a sense, the aversion to taxation is a form of protest too against bad governance. The failure of leadership has financial-legitimacy-moral dilemmas for Nigeria. One of the financial-legitimacy-moral dilemmas is the question of taxation, particularly whether Small and Medium Enterprises (SMEs) and other minor businesses ought to or ought not to pay tax to a rent-seeking patron-client government in this COVID-19 pandemic.

Like many governments in this COVID-19 pandemic, the Nigerian government imposed a lockdown on the country. As a consequence of the lockdown, many businesses shutdown and effectively had no source of revenue. Yet, without receiving any bailout or palliatives from the government, these businesses are required to meet their tax obligations to the government. The government only provided palliatives to a very few individual persons in a very few places, and yet in many cases the palliatives were looted by government officials (Orjinmo 2020). Bearing in mind that this time (COVID-19 era) is different, one wonders what is required of businesses in view of the taxation problem and the social contract between businesspersons and the government.

In view of the social contract theory of obligation, in this COVID-19 pandemic should businesses pay tax to a government that seems to have delegitimised itself by its exploitative actions in terms of taxation and delinquent omission in terms of the provision of public goods and social services? The Nigerian government at all tiers (federal, state and local) seldom respect the essence of taxation. Therefore, businesses often pay tax for nothing. For many businesses, as far as taxation is concerned, to pay or not to pay? that is the question. This article is aimed at teasing out this problem that may or may not be a moral dilemma. In view of certain ethical considerations, I show why in spite of social contract obligations there is no consensus or canonical agreement on whether, as law-abiding citizens and juridical persons (legal entities), businesspersons and businesses ought to or ought not to pay tax to the rent-seeking patron-client Nigerian government in this COVID-19 pandemic.

I divide the discussion into five sections. The first section is this introductory section. The second section is descriptive, the third and fourth sections are prescriptive while the fifth section is the conclusion. In the second section, in order to give us insights into the political economy condition that makes the taxation problem rife in 
Nigeria, I describe a particular case in which the underlying cause of the taxation problem is clearly manifest. In other words, I present a Nigerian condition from which the problem of taxation and the question of whether to pay or not to pay tax emanate. In the third section, I explain the taxation problem and discuss whether the problem can be considered to be a moral dilemma. In the fourth section, I apply the social contract approach to the problem. Then in the fifth section, I conclude the discussion with a recommendation to SMEs on how to navigate the murky waters of the taxation problem.

I am motivated to apply the social contract approach to the problem for the following reason. By its nature, taxation is transactional. You either pay because of the past, the present and/or the future. You pay for the services (and goods) you have received from the government (the past). You pay for the services (and goods) you are using or enjoying (the present). You pay for the services (and goods) you will or may receive, use or enjoy (the future). Although you pay as an individual, actually you equally pay as a member of a collective. Hence, as an individual, even if you do not enjoy certain services, you may still be taxed for such services because of your membership of a collective that enjoys such services. For instance, even if you use private hospitals and send your children to private schools, you may still be taxed for the funding of public hospitals and schools because you and your children are part of the collective that enjoys such public goods and social services. Therefore, taxation is a social contract between the state/government and persons/businesses. In the context of this article, taxation is a social contract between the government and businesspersons/small and medium enterprises (SMEs) and other minor businesses.

\section{Taxation without Reciprocity}

PricewaterhouseCoopers (PwC) (2010), one of the biggest auditing and consulting firms in the world, says "Nigeria is one of the few countries in the world where it is fashionable to evade tax" (4). To ascertain "Why SMEs and start-ups do not pay tax in Nigeria" and "Why...tax evasion [is] at an epidemic proportion in Nigeria", Victor Ekwealor (2017) conducted a survey which "shows that $80 \%$ of sampled Nigerian businesses and start-ups do not pay taxes" (s.p.). High rate of tax evasion exists among private persons and corporations (Ahunwan n.d.), "many Nigerian citizens and often, corporate entities do not even value and respect the tax system of the country.... government failure to provide fundamental amenities may be held responsible" (Gurama et al. 2015, 206). The following case shows how the government is responsible for the conditions that make individuals and businesses opt for tax avoidance and tax evasion.

On 29th May 1999, Nigeria ended its second spell of military rule and transitioned to democracy. This transition saw the lifting of economic and political sanctions that were placed on the country by the international community as a punishment for the oppressiveness and human rights abuses of military rule. One of the sectors that benefited from the new political and economic climate which made the environment conducive for investment was the hospitality sector. The sector boomed, hotels and restaurants sprang up almost everywhere to cater to people who, thanks to the lifting of economic sanctions, now have the means for leisure (Abumere 2019). 
Many of the hoteliers and restaurateurs are poor. Members of their families, both nuclear and extended, depend on them (Ibid.) - this is usual in a country that is home to the highest number of poor people in the world. In a country where, according to Nigeria's National Bureau of Statistics (NBS) (2020), over $40 \%$ of the population live below the poverty line, most of the hoteliers and restaurateurs had no personal funds to start their businesses. "With no funds of their own, they had to take loans with high interest rates in order to launch their new ventures. These businesses were soon jeopardised by political, security and religious developments" (Abumere 2019). For instance, in the commercial capital of, and the most populous state in, northern Nigeria, Kano State (which is also the second most populous state in Nigeria), Shari'a (Islamic law) was adopted on 21 s June 2000 (Ibid.). The adoption of Shari' $a$ in Kano State and one-third of Nigeria bankrupted, and continues to bankrupt most hospitality businesses.

Shari'a prohibits the admission of unmarried couples to hotels, the operation of nightclubs, beer parlours (pubs) and so on (Ibid.). The prohibition on the sale of alcohol is the most devastating impact of Shari'a on the hospitality sector; hotels, motels, guesthouses, restaurants, beer parlours (pubs) and night clubs that do not sell alcohol are not patronised (Ibid.). Hoteliers and restaurateurs who violate the dictates of Shari'a are fined heavily or even imprisoned while they forfeit their business or even see their hotels, restaurants, etc. demolished (Ibid.). However, observing the dictates of Shari'a meant hoteliers and restaurateurs had to reduce the number of services they offer their customers and "This led to fewer customers and, consequently, reduced earnings, leaving some hotels and related businesses running at a loss" (Ibid.).

Hisbah, that is, the Shari'a police, sees hotels, motels, guesthouses, restaurants, beer palours (pubs) and nightclubs as sin-centres (Ibid.) and therefore clamp down on them and even demolish some of them. Worse still, they are seen as sin-centres, targeted and bombed by Boko Haram Islamist terrorists (Fleming 2015). Consequently, hospitality entrepreneurs, namely hoteliers and restaurateurs, "risked losing money, freedom, and, ultimately, limbs and lives to terrorists" (Abumere 2019). In addition to the aforementioned risks, due to lack of security and infrastructure, hoteliers, restaurateurs and other business owners had "to provide their own security, pay thugs not to vandalise their businesses, pay the police bribes, provide their own electricity by using generators, provide their own water by sinking boreholes, and contribute money to fix roads to their hotels or guest houses" (Ibid.), restaurants and other businesses.

Yet, the Kano State government demands that hoteliers and restaurateurs must "pay corporate taxes, income taxes and property taxes" (Ibid.). Moreover, multiplicity of taxes is one of the biggest problems with taxation in Nigeria.

This means paying similar taxes on the same or substantially similar tax base. Examples of multiple taxes include Companies Income Tax, Information Technology Tax (NITDA Levy), Education Tax, Nigerian Content Development Levy all of which are based on income or profits and Value Added Tax, Sales Tax and Hotel Consumption Tax all based on sales (PwC 2010, 2). 


\section{Is the Taxation Problem a Moral Dilemma?}

The political economy problem described in the preceding section, as earlier mentioned, has financial-legitimacy-moral dilemmas for Nigeria. One of the financiallegitimacy-moral dilemmas, as earlier mentioned, is the question of taxation, particularly whether SMEs and other minor businesses ought to or ought not to pay tax to a rent-seeking patron-client government. I am not talking about corporate tax in general, I am specifically talking about the aforementioned businesses - therefore, multinational corporations, other large corporations, big businesses and big businesspersons are not within the remit of my discussion. I am only concerned about SMEs, minor entrepreneurs, small business owners in the informal economy, petty traders and artisans. Hereafter, I will refer to these businesses as Minor Business Ventures (MBVs). My aim in discussing the taxation problem is to show what, in view of certain ethical considerations, the social contract approach will require of the MBVs. In other words, in view of social contract obligations, should the MBVs pay tax to a government that seems to have delegitimised itself by its exploitative actions in terms of taxation and delinquent omission in terms of the provision of public goods and social services?

As already mentioned, by its nature, taxation is transactional. You either pay because of the past, the present and/or the future. You pay for the services (and goods) you have received from the government (the past). You pay for the services (and goods) you are using or enjoying (the present). You pay for the services (and goods) you will or may receive, use or enjoy (the future). The Nigerian government at all tiers seldom respect the essence of taxation. Therefore, MBVs often pay tax for nothing. They seem to have lost faith in the tax system. As far as the MBVs are concerned, taxation in Nigeria is a form of exploitation of the MBVs by the government. As PricewaterhouseCoopers (PwC) (2010) says, "From internal conflicts to clear ambiguities, the Nigerian tax regime can be rightly described as draconian" (1). Furthermore, PwC (2010) says that "Different taxes are sometimes introduced in a haphazard manner contrary to the new National Tax Policy" (9).

For many of the MBVs, as far as taxation is concerned, to pay or not to pay? that is the question. Some grudgingly pay out of fear of the coercive apparatus of the state, some pay out of duty, some do not pay, and others do not know whether to pay or not to pay. This indicates that an individual MBV's payment of tax may be based on different grounds emanating from virtue ethics, consequentialism, deontology, and so on. For those who pay out of fear, those who pay out of duty, those who do not pay, and those who do not know whether to pay or not to pay, there is no simple moral condemnation of or justification for their actions or omissions. Whether one thinks they are right or wrong depends on the moral theory one subscribes to, virtue ethics, consequentialism, deontology, and so on.

The taxation problem seems to be a moral dilemma. As will be evident in the remainder of this section and the next section, there is lack of definitive answer to the question whether MBVs ought to or ought not to pay tax to the Nigerian government. If paying is morally right and not paying is morally wrong and vice versa, in spite of the lack of definitive answer to the taxation problem, fundamentally the MBVs do not face a moral dilemma. However, if whether the MBVs pay or do not pay they are doing something morally wrong, then fundamentally they face a moral dilemma. In this section, I will tease out whether the taxation problem they face is a moral dilemma. 
In a moral dilemma, "an agent regards himself as having moral reasons to do each of two actions, but doing both actions is not possible" (McConnell 2018, sect. 2). This is because:

The crucial features of a moral dilemma are these: the agent is required to do each of two (or more) actions; the agent can do each of the actions; but the agent cannot do both (or all) of the actions. The agent thus seems condemned to moral failure; no matter what she does, she will do something wrong (or fail to do something that she ought to do) (McConnell 2018, sect. 2).

In addition, if one requirement supersedes the other, then there is no moral dilemma. So, for there to be a moral dilemma, among the conflicting requirements, no one requirement should supersede the other (Sinnott-Armstrong 1988; McConnell 2018). If the requirement to pay tax supersedes the requirement not to pay tax, then there is no moral dilemma. And if the requirement not to pay tax supersedes the requirement to pay tax, likewise there is no moral dilemma.

In their empirical work on taxation in Nigeria, Virginia Nnenna Onyeka and Carol Nwankwo (2016) discovered that:

Tax evading has become the favourite crime of the Nigerian, so popular that it makes armed robbery seem like minority interest. It has become so widespread that there now exist a cash economy of vast proportions over which the taxman has no control and which is growing at several times the rate of the national economy....According to the Nigerian Stock Exchange, 85\% of corporate tax revenue in the country accrues from the 257 companies listed on the exchange compared to the 30,000 companies registered with the Corporate Affairs Commission (160).

Onyeka and Nwankwo (2016) went on to conclude that "Tax evasion is a serious problem in Nigeria which arises from many sources including... lack of faith in the ability of government to utilise tax revenue well (164). Also, Akinyomi and Okpala (2013), in their own empirical work on taxation in Nigeria, reached the following conclusion:

This study investigated the factors which influence tax avoidance and tax evasion in Nigeria. The results of the study revealed the following: (i) That the low quality of the service in return for tax does significantly influence tax avoidance and evasion in Nigeria. (ii) That tax system and perception of fairness do significantly influence tax avoidance and evasion in Nigeria. (iii) That low transparency and accountability of public institutions do significantly influence tax avoidance and evasion in Nigeria. (iv) That high level of corruption does significantly influence tax avoidance and evasion in Nigeria (111).

In the Nigerian case, from a deontological perspective, the requirement to pay tax supersedes the requirement not to pay; in fact, the requirement not to pay does not even exist. Therefore, from a deontological perspective, there is no moral dilemma in the case. On the other hand, from a consequentialist perspective, since only few rent- 
seeking politicians and civil servants are benefitting from the tax while they are neglecting the actual purpose of the tax, then the payment of tax has no positive moral consequence. In this case, it is not clear whether the duty not to pay overrides the duty to pay, but it seems so.

However, from a utilitarian perspective, one can argue that since only few rentseeking politicians and civil servants are benefitting from the taxes rather than many people, the majority of society or the whole society benefitting, then the duty not to pay overrides the duty to pay. Nevertheless, on utilitarian grounds, since not paying means only the tax payer will benefit rather than the few politicians and civil servants, and since the rent-seeking politicians and civil servants outnumber the tax payer, then the tax payer ought to pay. If this kind of argument seems perverse, it is because certain utilitarian conclusions seem perverse. After all, it is in the nature of utilitarianism to throw up perverse conclusions every now and then.

This case is simultaneously like the famous Socratic and Sartrean cases of moral dilemma in one respect and unlike them in another respect. In the Sartrean case in which a young man was torn between avenging the death of his brother and taking care of his mother (Sartre 1957), the two requirements are distinct and separate. Although they are either/or case like the Nigerian case of either to pay or not to pay, the requirement to avenge his brother is not the direct opposite of the requirement to take care of his mother. Whereas, in the Nigerian case the requirement to pay tax is the direct opposite of the requirement not to pay tax.

In the Socratic case, a friend borrowed a weapon and must decide whether to return it to the owner who seems likely to commit a crime with it due to his mental state at the time the weapon is supposed to be returned (Plato [c.375 BC]2012, Book I). The Nigerian case is similar to the Socratic case in that in both cases, prima facie, there is a requirement to perform a duty - given prior commitments. In the Socratic case, the prior commitment is a promise, whereas in the Nigerian case the prior commitment is obedience to the laws of the state. However, the two cases differ in the sense that in the Socratic case the owner of the weapon has no prior commitment and reciprocal duty to his friend - the borrower. Whereas in the Nigerian case, the government has a prior commitment and reciprocal duty to the tax payer. The government is committed to providing certain goods and services for the tax payer before, during and after the payment of the tax - in fact, this duty is a continuum.

In law, tax evasion is a crime. However, it is worthwhile to note that law does not equal ethics, legality does not equal morality, that which is legal is not necessarily moral too, and that which is illegal is not necessarily immoral too. While tax evasion is legally wrong, and usually morally wrong, it may not be morally wrong in some circumstances. After all, legality does not equal morality. I admit that in law, businesses are required to pay corporate tax and related taxes except the government decides otherwise by way of tax holidays, free zones, and so on. Therefore, I admit that it is illegal for the MBVs not to pay tax. In other words, I admit that they commit a crime if they fail to pay their taxes. Nevertheless, I am not concerned about law and legality; I am concerned about ethics and morality. For this reason, in the next section, I shall turn to the social contract approach in an attempt to find out what exactly the businesspersons and MBVs as law-abiding citizens and juridical persons (legal entities) ought to do or ought not to do. 


\section{The Social Contract Approach to Obligations}

The social contract approach to business ethics, as the name implies, is a derivative of the famous social contract methodological device used by Thomas Hobbes (1651), John Locke (1980), Jean-Jacque Rousseau (1997) and Immanuel Kant (1996[1785]). Using the social contract methodological device, Hobbes (1651), Locke (1980) and Rousseau (1997) hypothetically explain the ahistorical transition of societies from the state of nature to the modern state. As thought experiments, Hobbes', Locke's and Rousseau's social contracts have no truth-value. Nevertheless, they may be helpful or unhelpful in explaining the relationship between businesses and government, and the obligations both parties owe to each other. The social contract approach to business ethics offers an explanation of the relationship between businesses and the society and the obligations the former owe the latter.

Adopting the methodological device, according to the social contract approach in business ethics, "all businesses are ethically obligated to enhance the welfare of society by satisfying consumer and employee interests without violating any of the general canons of justice" (Hasnas 1998, 29). In this approach, what businesses owe the government or state is respect for the general canons of justice, and this obligation is derived from a hypothetical contract in which businesses have consented to respect the general canons of justice in return for the goods and services (governance) which the government or state provides for the businesses and the general society.

Taxation is a compulsory levy imposed on persons (citizens and residents) and corporations by the government in other to generate revenue for public expenditure on public goods and services (Nightingale, 1997). However, in the case of Nigeria, why the government generates revenue from levying taxes on persons and corporations, it does not, generally, provide taxpayers with infrastructure. Whatever infrastructure or social amenities that exist are in a deplorable condition (Fafunwa 2005) and taxpayers' expectation that the government will provide social amenities are unfulfilled (Lambo 2005; Obaji 2005).

There is no doubt that government's failure to provide infrastructure and services hinders businesspersons from achieving the aim of their businesses.

Tax paying culture is poor in Nigeria due largely to the lack of transparency and accountability on the part of government as taxpayers' money is rarely seen at work. When people have to pay taxes and also provide their own infrastructure this effectively increases tax rates and costs to taxpayers (PwC 2010, 9).

Therefore, one may argue that businesspersons can be morally justified to refuse to pay taxes to government both as a way of compensating for the government's failure to provide reciprocal goods and services and as a way of compensating for the consequent loss of revenues by the MBVs. I will call this scenario regular scenario only for the purpose of classification and then comparison with a different scenario that I will call irregular scenario. Government's failure to provide infrastructure and services leads to loss of revenue which in turn, in many cases in Nigeria, leads to failing businesses and very poor business owners. In view of social contract obligations, the government has abnegated its responsibilities. Therefore, the violation of government's taxation rights in order to prevent the failure of a business seems reasonable. The prevention of the 
failure of business may not be an end in itself; it may be a means to repay bank loans and to cater for dependent family members. I will call this scenario irregular scenario in contradistinction to the aforementioned regular scenario.

In view of the social contract approach, ceteris paribus, the MBVs are supposed to pay taxes. However, on the one hand, in terms of the regular scenario, since the government has failed in its obligations to the MBVs, the social contract approach can justify the refusal to pay taxes to the government. In the social contract, obligations are transactional. Therefore, one party's failure to fulfil its obligations can lead to the moral justification of the other party's refusal to fulfil its own obligations.

On the other hand, let us consider the irregular scenario. In view of the social contract approach, the MBVs have a duty to respect government's taxation rights and a duty to repay their loans. However, they can only do one. While the canons of justice of the society deem the violation of government's taxation rights to be a crime, failure to repay loans and going bankrupt is seen to be part of the unpleasant side of business. Likewise, the cannons of justice of society will not permit the commission of a crime (the violation of government's taxation rights) in order to cater for dependent family members.

Kantian deontology is helpful in understanding why the canons of justice of society will not permit the violation of government's taxation rights. According to Kant (1996[1785]), if an "action would be good merely as a means to something else the imperative is hypothetical; if the action is represented as in itself good, hence as necessary in a will in itself conforming to reason, as its principle, then it is categorical" (4: 414) (emphasis in original). For Kant (1996[1785]):

all imperatives command either hypothetically or categorically. The former represent the practical necessity of a possible action as a means to achieving something else that one wills (or that it is at least possible for one to will). The categorical imperative would be that which represented an action as objectively necessary of itself, without reference to another end (4: 414) (emphasis in original).

In view of the distinction between the hypothetical imperative and the categorical imperative, refusing to pay taxes to the government will be hypothetical imperatives. I will use the regular and irregular scenarios in the preceding paragraphs of this section to illustrate my point. Firstly, in terms of the regular scenario, while the entrepreneurs acknowledge that ceteris paribus they have an obligation to pay taxes, they are only refusing to pay taxes as a means to compensate for the government's failure to provide infrastructure and services. In other words, when the government provides infrastructure and services, the MBVs will pay their taxes, but when the government fails to provide infrastructure and services, the MBVs will not pay their taxes.

Secondly, in terms of the irregular scenario, while the MBVs acknowledge that ceteris paribus they have an obligation to respect government's taxation rights, they go ahead to violate such rights in order to repay their loans and cater for their dependent family members. In other words, if they have other means to achieve their ends, they will not violate government's taxation rights, and if they do not have other means to achieve their ends then they will violate government's taxations rights. However, the categorical imperative abhors such practical calculations. For the categorical 
imperative, obligations are non-transactional. So, the entrepreneurs' obligations to pay taxes still hold irrespective of the failure of government and the lack of other means to repay loans and cater for dependent family members.

Nevertheless, if the entrepreneurs think that refusing to pay taxes to a nonaccountable government in order to repay loans and cater for dependent family members is morally justified, then they will have to universalise this principle. The principle will be as follows. In all places and at all times, any persons who find themselves in a similar circumstance as the entrepreneurs should act in the same way. As Kant (1996[1785]) says, there is:

only one categorical imperative and it is this: act only in accordance with that maxim through which you can at the same time will that it become a universal law... act as if the maxim of your action were to become by your will a universal law of nature (4: 421) (emphasis in original).

In our world today, while the universalisation of the payment of taxes and the respect for government's taxation rights seems more acceptable, the universalisation of the nonpayment of taxes and the violation of government's taxation rights seems less acceptable.

To buttress my point that in spite of social contract obligations, there is no consensus or canonical agreement on whether MBVs ought to or ought not to pay tax to the Nigerian government, I will look at a totally different approach. Even if a totally different approach is applied to the taxation problem, the problem will not be closer to being resolved than it is when the social contract approach is applied to it. For instance, an application of the stockholder approach to the taxation problem, as shown below, still leaves the problem intractable.

According to the stockholder approach, "managers are obligated to follow the (legal) directions of the stockholders, whatever these may be" (Hasnas 1998, 22). In other words, “a business's or business person's ordinary responsibilities are to manage the business and expend business resources so as to accomplish the specific purposes for which the business was organised" (Hasnas 1998, 21). In this vein, Milton Friedman (1970) famously argued that the primary responsibility of businesses is "to make as much money as possible while conforming to the basic rules of the society, both those embodied in law and those embodied in ethical custom" (32-33).

In view of the stockholder approach, and particularly the profit maximisation argument, there is no doubt that government's failure to provide infrastructure and services hinders businesspersons from achieving the aim of their businesses. Therefore, as earlier mentioned, one may argue that businesspersons can be morally justified to refuse to pay taxes to government both as a way of compensation for the failure and the consequent loss of revenues - this is the regular scenario discussed in the preceding paragraphs of this section.

If the stockholder approach and the profit maximisation argument seem to be somewhat reasonable when applied to the moral issue of taxation, it even seems to fare better when applied to the cases of failing businesses and very poor business owners. If it is true that the primary responsibility of businesses is profit maximisation, then the violation of government's taxation rights in order to prevent the failure of a 
business seems reasonable. The prevention of the failure of a business may not be an end in itself; it may be a means to repay bank loans and to cater for dependent family members - this is the irregular scenario discussed in the preceding paragraphs of this section.

However, the stockholder approach cannot justify why government's taxation rights should be violated in order to meet the financial obligations of entrepreneurs when such obligations are not part of the essence or primary responsibility of businesses. In both the regular and irregular scenarios, refusing to pay taxes is illegal. Therefore, in view of the stockholder approach such illegality is likely to be deemed immoral because the stockholder approach "does not assert that managers have a moral blank check that allows them to ignore all ethical constraints in the pursuit of profits. Rather, it states that managers are obligated to pursue profit by all legal, non-deceptive means" (Hasnas 1998, 22).

In summary, the lynchpin of the stockholder analysis is that entrepreneurs should not only be concerned with cost/benefit analysis, efficient procedures and return on investment, but also with ensuring that illegality and deception are not part of their business strategies. At a more fundamental level, stockholders as principals are concerned with the accountability mechanisms that would help close the asymmetry of information between agents and themselves, thus aligning the interests of agents with their own. If deception happens it is because agents pursue their interests at the expense of the principals, that is, their interests are not aligned. That could help us better understand the forces at play in Nigeria.

Nevertheless, the above would only be pointing us to the fact that there is no consensus or canonical agreement on whether, as law-abiding citizens and juridical persons (legal entities), the businesspersons and MBVs should pay tax to a government that seems to have delegitimised itself by its exploitative actions in terms of taxation and delinquent omission in terms of the provision of public goods and social services. We still need to know what exactly the businesspersons and MBVs ought to do and ought not to do as law-abiding citizens and legal entities. This, the stockholder approach cannot tell us.

\section{Conclusion}

To reiterate, Nigeria's moral economy has financial-legitimacy-moral dilemmas for Nigeria. Taxation is one of the financial-legitimacy-moral dilemmas, and it especially affects MBVs because they have to make a very difficult moral decision whether to pay or not to pay tax to a rent-seeking patron-client government. In my discussion of the taxation problem, I showed what the social contract approach requires of the MBVs. Evidently, the application of the social contract approach to the taxation problem shows that, whether it is morally wrong or morally right for the MBVs to pay their taxes depends on the ethical theory to which one subscribes. There is no definite answer to whether the MBVs ought to or ought not to pay tax to the rent-seeking patron-client Nigerian government.

Applying the social contract approach to the taxation problem, I showed why there is no consensus or canonical agreement on whether, as law-abiding citizens and juridical persons (legal entities), the businesspersons and MBVs ought to or ought not to pay tax to the rent- 
seeking patron-client Nigerian government. However, I will conclude by averring that the MBVs must always be conscious of their Corporate Social Responsibility (CSR) when deciding whether to pay or not to pay tax to a government that seems to have delegitimised itself by its exploitative actions in terms of taxation and delinquent omission in terms of the provision of public goods and social services.

CSR is motivated by deontological rather than consequentialist moral theory because it asserts that MBVs owe and must fulfil certain moral obligations to the public irrespective of the consequences such obligations have for MBVs. In view of CSR, refusal to pay tax will be a form of negative externality because taxation is part of a social contract in which an MBV does not only pay as an individual MBV, but also as a part of a collective. As earlier mentioned, although you pay tax as an individual, actually you equally pay as a member of a collective. Hence, as an individual, even if you do not enjoy certain services, you may still be taxed for such services because of your membership of a collective that enjoys such services.

Negative externalities are costs "accruing to an individual or group - a third party that is external to a market transaction" (McConnell et al., 2009, 340) (emphasis in original). In the context of the taxation problem, the public will suffer the cost of the MBVs decision not to pay tax while the MBVs enjoy the benefits of such decision. This seems to be tantamount to privatising profits and socialising risks and losses. While this is efficient for the MBVs, it may or may not be moral for them. Therefore, the balancing of efficiency and morality is another problem MBVs have to deal with.

In a nutshell, the MBVs:

face a dilemma between business ethics and cost/benefit analysis, between moral procedures and efficient procedures, and between the moral consequences of their actions and return on investment. The ability to balance these moral and business challenges is the hallmark of [... an ethical] business; for these moral and business challenges are not mutually exclusive (Abumere 2015, 108).

Finally, CSR demands that the MBVs should not only be socially responsible to themselves and shareholders, but also to the public. Therefore, I think, in their decision-making process, when deciding whether to pay tax or not to pay tax, the MBVs should be conscious of their CSR.

Authors' Contribution None.

Funding No funding was received to assist with the preparation of this manuscript.

Availability of Data and Material Not Applicable.

Code Availability Not Applicable.

\section{Declarations}

Conflict of Interest/Competing Interests None. 


\section{References}

Abumere, F. A. (2015). Different perspectives on global justice: A fusion of horizons. Publication at Bielefeld University (PUB).

Abumere, F. A. (2019). Shari'a and the Hospitality Industry in Nigeria. In F. Allhoff, \& A. Sager (Eds), Business cases in ethical focus (s.p.). Broadview Press.

Achebe, C. (1983). The trouble with Nigeria. Ibadan: Heinemann.

Ahunwan, B. (n.d.). New national tax policy approval in late December '08 - Nigeria. HG.org Legal Resources. https://www.hg.org/legal-articles/new-national-tax-policy-approved-in-late-december-08nigeria-5944. Accessed 12 Jan 2021.

Akinyomi, O. J., \& Okpala, K. (2013). Appraisal of factors influencing tax avoidance and evasion in Nigeria. International Journal of Research in Commerce \& Management, 4(5), 107-111.

Ekwealor, V. (2017). Tax compliance: Why SMEs and start-ups in Nigeria do not pay taxes. Techpoint.Africa, (March 16).

Fafunwa, A.B. (2005). Collapse in educational system: Our collective failure. The Guardian, October 30.

Fleming, L. (2015). Secret Nigerian drinking dens in Kano. BBC News, March 21.

Friedman, M. (1970). The social responsibility of business is to increase its profits. The New York Times Magazine, September 13.

Gurama, Z., Mansor, M. B., \& Pantamee, A. A. (2015). Tax evasion and Nigeria tax system: An overview. Research Journal of Finance and Accounting, 6(8), 202-211.

Hasnas, J. (1998). The normative theories of business ethics: A guide for the perplexed. Business Ethics Quarterly, 8(1), 19-42.

Hobbes, T. (1651). Leviathan: Or, the matter, forme, and power of a common-wealth ecclesiaticall and civill. London: Andrew Crooke.

Kant, I. (1996[1785]). Groundwork of the metaphysics of morals. Immanuel Kant: Practical philosophy. M. J. Gregor (trans. \& Ed.). Cambridge: Cambridge University press.

Lambo, E. (2005). Minister decries state of health system. The Guardian, October 13.

Locke, J. (1980). Second treatise on civil government. C. B. MacPherson (Ed.). Indianapolis: Hackett.

McConnell, C. R., Brue, S. L., \& Flynn, S. M. (2009). Economics: Principles, problems, and policies. New York: McGraw-Hill/Irwin.

McConnell, T. (2018). Moral dilemmas. The Stanford Encyclopedia of Philosophy, Fall ed. <https://plato. stanford.edu/archives/fall2018/entries/moral-dilemmas/>. Accessed 3 Sept 2020.

NBS. (2020). 2019 poverty and inequality in Nigeria: Executive summary. National Bureau of Statistics, https://nigerianstat.gov.ng/elibrary?queries[search]=poverty. Accessed 12 Jan 2021.

Nightingale, K. (1997). Taxation: Theory and practice. Upper Saddle River: Financial Times/Prentice Hall.

Obaji, C. (2005). Nigeria cannot justify N40billion spent on education. The Punch, October 19.

Onyeka, V. N., \& Nwankwo, C. (2016). The effect of tax evasion and avoidance on Nigeria's economic growth. European Journal of Business \& Management, 8(24), 158-166.

Orjinmo, N. (2020). Why Nigerian looters are targeting COVID-19 aid. BBC News, October 26.

Plato. (2012[c. 375 BC]). Republic. R. Christopher (Trans). London: Penguin.

PwC. (2010). Nigeria @ 50: Top 50 tax issues. Research document. PricewaterhouseCoopers, file:///run/arc/ sdcard/write/emulated/0/Documents/nigeria-top-50-tax-issues.pdf.

Rousseau, J-J. (1997). The social contract and other later political writings. V. Gourevitch (trans. \& Ed.). Cambridge: Cambridge University press.

Sartre, J.-P. (1957). Existentialism is a humanism. P. Meiret (trans.). In W. Kaufmann (Ed.), Existentialism from Dostoevsky to Sartre (pp. 287-311). New York: Meridian.

Sinnott-Armstrong, W. (1988). Moral Dilemmas. Oxford: Basil Blackwell.

Publisher's Note Springer Nature remains neutral with regard to jurisdictional claims in published maps and institutional affiliations. 